\title{
EVALUATING THE SUITABILITY OF AIRBUS WORLDDEM FOR FLOOD MODELLING IN DATA-SCARCE REGIONS: THE CASE STUDY OF THE MEGARUMA RIVER, MOZAMBIQUE
}

\author{
MARÍA BERMÚDEZ ${ }^{1}$, MANUEL ÁLVAREZ ${ }^{1}$, JERÓNIMO PUERTAS ${ }^{1}$, \\ ENRIQUE PEÑA ${ }^{1} \&$ ANTÓN AMADO ${ }^{2}$ \\ ${ }^{1}$ Water and Environmental Engineering Group, University of A Coruña, Spain \\ ${ }^{2}$ ICARTO S.L., A Coruña, Spain
}

\begin{abstract}
The provision of good topographic data is critical to the application of flood inundation models. However, high resolution accurate Digital Elevation Models (DEMs), such as those obtained by LiDAR, are currently unavailable in many regions of the world. Satellite-derived DEMs can thus constitute a suitable alternative. The open access SRTM DEM, with horizontal resolutions of 90 or 30 $\mathrm{m}$, has received much attention from hydraulic modellers. These data, if appropriately treated, can support large-scale flood inundation modelling, providing reasonably accurate risk assessments. Nonetheless, commercial DEMs of higher resolution and accuracy, such as Airbus WorldDEM (12 m resolution), have recently become available worldwide. Their potential for hydraulic modelling has been less explored, but they might eventually replace SRTM data for large-scale modelling, while allowing for more detailed local flood studies worldwide. In this study we evaluate the utility of Airbus WorldDEM topographic data for flood modelling in data-scarce regions. A $3.5-\mathrm{km}$ reach of the Megaruma River in Mozambique is used as a test case. A shallow water model is developed for the reach, based on Airbus WorldDEM data. The hydrological consistency of the DEM is analyzed, and the need for hydrological conditioning for realistic hydrodynamics. The suitability with respect to flood frequency is also evaluated, the hypothesis being that the limitations of the DEM would be less relevant for the modelling of very high flows. The results show that, in spite of the higher resolution and the hydrological editing to which it is subject, WorldDEM dataset still presents limitations that prevent it from being directly used without further processing in local flood modelling studies.
\end{abstract}

Keywords: digital elevation model, flood modelling, flood wave propagation, hydraulics, Mozambique.

\section{INTRODUCTION}

Flood inundation models are essential tools for flood risk management. They provide information on flood extent and timing, as well as on flow characteristics that serve as a basis to develop flood hazard maps. Hydrodynamic models which solve the two-dimensional shallow water equations are a well-established approach in cases where flows can be strongly two-dimensional, such as river confluences [1], flows over extensive flat floodplains [2] or urban areas [3].

The provision of good topographic data is critical to the application of such models. Current computational resources allow us to set up flood inundation models of river reaches at very small spatial scales [4], [5]. However, this requires adequate topographic data at such scales. High resolution accurate Digital Elevation Models (DEMs), such as those obtained by LiDAR, are currently unavailable in many regions of the world.

Satellite-derived DEMs can thus constitute a suitable alternative. The open access Shuttle Radar Topography Mission (SRTM) DEM, with horizontal resolutions of 90 or $30 \mathrm{~m}$, has received much attention from hydraulic modellers. These data, if appropriately treated, can support large-scale flood inundation modelling, providing reasonably accurate risk assessments [6], [7]. Other existing open access online digital elevation models, such as the 
Advanced Spaceborne Thermal Emission and Reflection Radiometer (ASTER) DEM have also been applied in flood modelling [8]. However, STRM has emerged as the favoured choice in comparative studies due to its greater feature resolution, reduced number of artifacts and lower noise [9].

Commercial DEMs of higher resolution and accuracy, such as Airbus WorldDEM (12 m resolution), have recently become available worldwide. Their potential for hydraulic modelling has been less explored, but they might eventually replace SRTM data for largescale modelling, while allowing for more detailed local flood studies worldwide.

This study is part of the work of the Water and Environmental Engineering Group of the University of a Coruña (Spain) on cooperation projects aimed at institutional strengthening of the Regional Water Management Administration in Northern Mozambique. In this datascarce region, the SRTM DEM has been successfully used as main source of topographic data for dam-break flood analysis [10]. However, a terrain reconditioning procedure was needed to improve its accuracy and to ensure that it was hydrologically consistent. The possibility of having an alternative or complementary source of topographic data that requires less preprocessing effort is very attractive for future practical studies.

In this study we evaluate the utility of Airbus WorldDEM topographic data for flood modelling in the data-scarce region of Cabo Delgado, Mozambique. A 3.5-km reach of the Megaruma River is used as a test case. A two-dimensional shallow water model of the reach is set up. The hydrological consistency of the DEMs is analysed, and the need for hydrological conditioning for realistic hydrodynamics.

\section{MATERIALS AND METHODS}

\subsection{Study site and cartographic information}

The Megaruma River flows through Cabo Delgado province in northeastern Mozambique (Fig. 1). It has a length of approximately $201 \mathrm{~km}$ and an average slope of $2.24 \%$. The Megaruma River basin is an internal basin of Cabo Delgado, with an extension of $5065 \mathrm{~km}^{2}$. Its average annual precipitation $(\mathrm{P})$ reaches $927 \mathrm{~mm}$, while the potential evapotranspiration (PET) is $1346 \mathrm{~mm}$. The aridity index (P/PET) shows that the climate is humid.

The studied reach has a length of $3.517 \mathrm{~km}$ and an average river width of $0.146 \mathrm{~km}$ (Fig. 1). The mean annual flow (Qo) is estimated to be $357.5 \mathrm{~m}^{3} / \mathrm{s} \mathrm{(Fig.} \mathrm{2)} \mathrm{[11],} \mathrm{[12].} \mathrm{The} \mathrm{reach} \mathrm{is}$ located in the lower part of the basin, which is frequently affected by flooding. It is estimated that around 7000 people and 1700 buildings are exposed to the 500 -year flood event (Fig. 3) [12].

The source of topographic data for this study was the Airbus WorldDEM. This product is based on the radar satellite data acquired during the TanDEM-X Mission, with 0.4 arc-second resolution (about $12 \times 12 \mathrm{~m}$ at the equator). This DEM is a consumer-ready product that has been hydrologically edited to reduce the effect of radar-specific artifacts [14]. Water bodies are identified and delineated and set to a plausible elevation. In the case of rivers, monotonic flowing elevations are enforced.

\subsection{Hydraulic modelling}

In order to evaluate the hydrological consistency of the DEM, a flood inundation model of the reach was set up using the software Iber [15], [16]). The model solves the 2D depthaveraged shallow water equations by means of a finite volume method. 

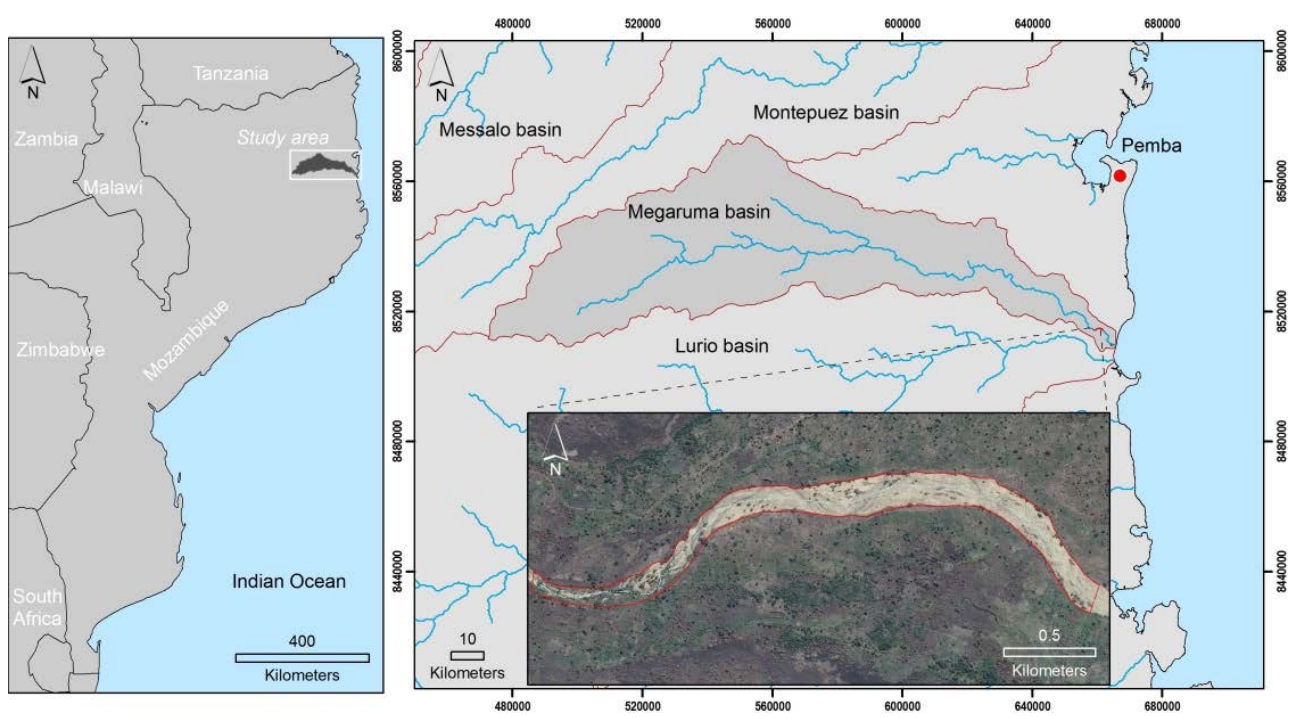

Figure 1: Location of the Megaruma River basin and the analysed river reach. Aerial image of the reach (inset figure).

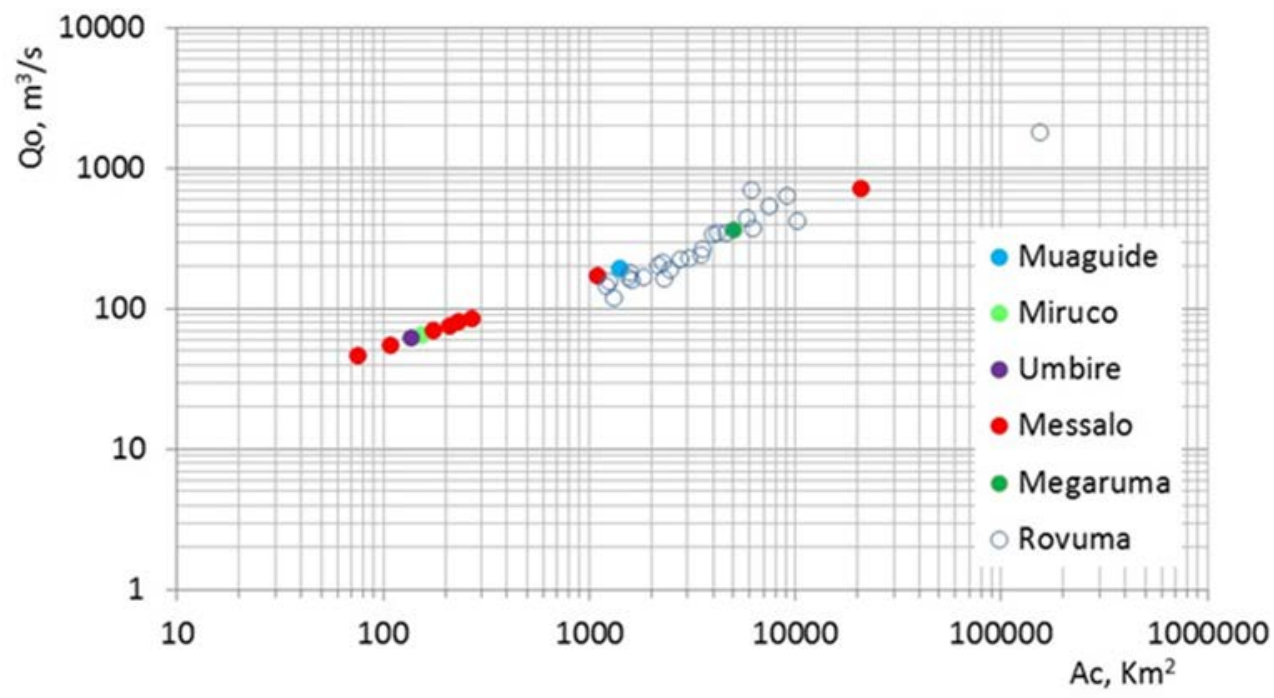

Figure 2: Mean annual flow (Qo) vs basin area (Ac) for sub-basins in the region. (Source: Results obtained in the framework of the project SIXHIARA [12] and obtained by SWECO in the Rovuma catchment [13].) 


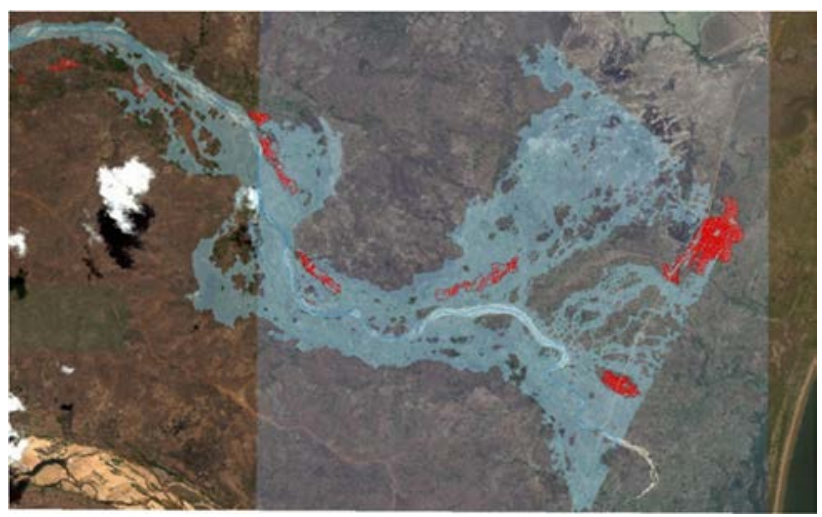

Figure 3: Location of rural settlements in the lower part of the Megaruma River (in red) within the 500-year flood extent. (Source: Numerical model results obtained in the framework of the project SIXHIARA [12].)

Two model configurations were set-up. In the first one, the original WorldDEM data was used to define the model topography. In the second one, a terrain conditioning process was applied to the DEM data. The reconditioning process is based on the so-called stream burning procedure, which is used to correct surface drainage patterns derived from DEM [17]. The vector river network derived from an aerial image is converted into a raster river with the same spatial resolution as the DEM. This raster river network is burnt into the un-conditioned DEM, so that the elevation values are artificially lowered at cells that are part of this raster drainage. The burning depth is variable along the longitudinal profile of the river, considering the envelope of the minimum elevations of the original DEM, as shown in Fig. 4.

In both configurations, typical physical values were selected for the Manning roughness coefficient, which is the only parameter of the model. Water depth maps for constant flows of different magnitude (up to $400 \mathrm{~m}^{3} / \mathrm{s}$ ) were computed.

\section{RESULTS AND DISCUSSION}

Fig. 5 shows the predicted water depth field for a discharge of $50 \mathrm{~m}^{3} / \mathrm{s}$. In spite of the low discharge value, well below the mean annual flow, significant flooding occurs if the original digital elevation model is used (Fig. 5(a)). This is a first indicator that non-physical elevation variations might be resent in the original DEM, affecting flow predictions.

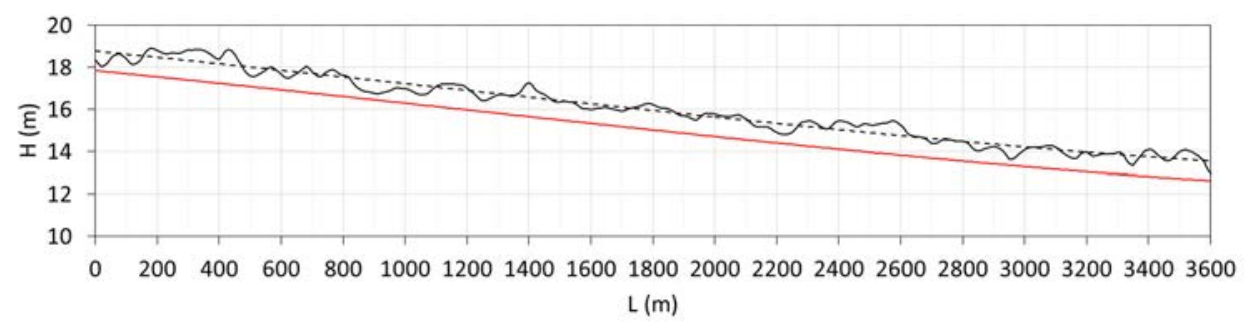

Figure 4: Longitudinal profile along the river thalweg with the original digital elevation model (black) and the hydrologically-conditioned digital elevation model (red). The average slope of the reach is plotted in a dotted line. 


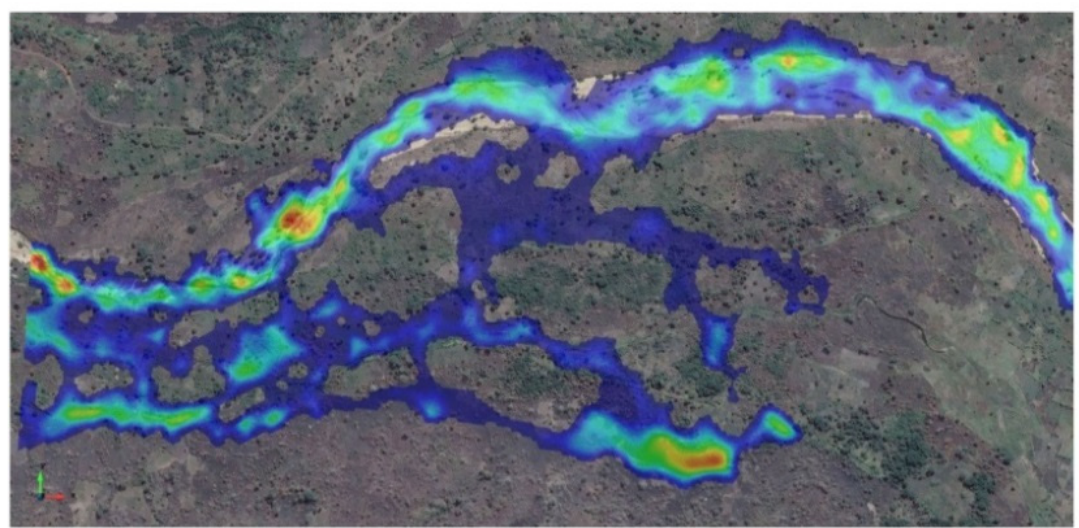

Depth (m)

(a) Original DEM

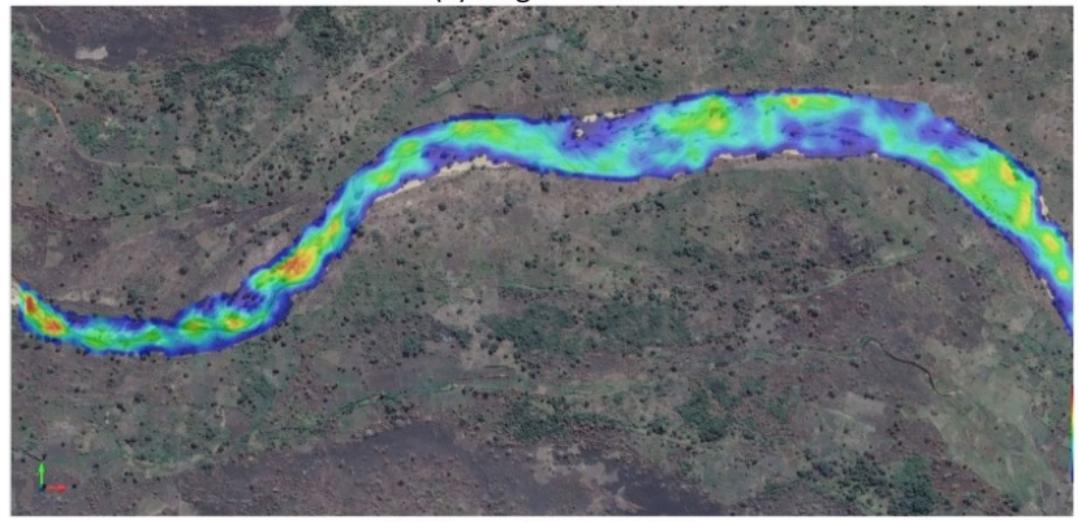

Depth (m)

(b) Reconditioned DEM
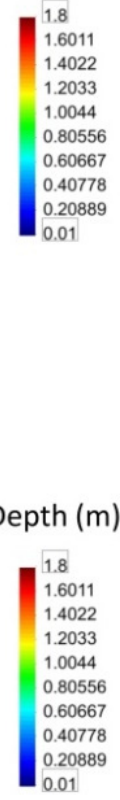

Figure 5: Predicted water depth map in the reach with the original DEM and the conditioned DEM for a discharge of $\mathrm{Q}=50 \mathrm{~m}^{3} / \mathrm{s}$.

In a second step, the average reach characteristics obtained with the two model configurations were compared. The average mean depth vs. discharge relationships in the reach are shown in Fig. 6. In order to derive estimates of bankfull width and depth for the reach, the relationships obtained by Moody and Troutman [18] between this variables and the discharge were used. The mean annual flow Qo can be considered representative of bankfull discharge [19]. For a Qo of $357 \mathrm{~m}^{3} / \mathrm{s}$, a bankfull width of $136 \mathrm{~m}$ and a bankfull depth of $1.57 \mathrm{~m}$ were obtained. This value of width is consistent with the width estimated from the aerial image, which is $146 \mathrm{~m}$ of average in this reach. As can be seen in Fig. 6, the average depth values obtained with the original DEM never reach the most likely estimate of bankfull depth of $1.57 \mathrm{~m}$. The average depth is only in the order of $1 \mathrm{~m}$ for the mean annual flow. The average depth vs. discharge curve becomes practically horizontal from flows higher than 100 $\mathrm{m}^{3} / \mathrm{s}$. This suggests that the bankfull capacity of the stream is considerably underestimated when the original DEM is used. On the contrary, the average depth vs. discharge curve obtained with the hydrologically-conditioned DEM is consistent with the above estimates.

The average depth for the mean annual flow is $1.73 \mathrm{~m}$. 


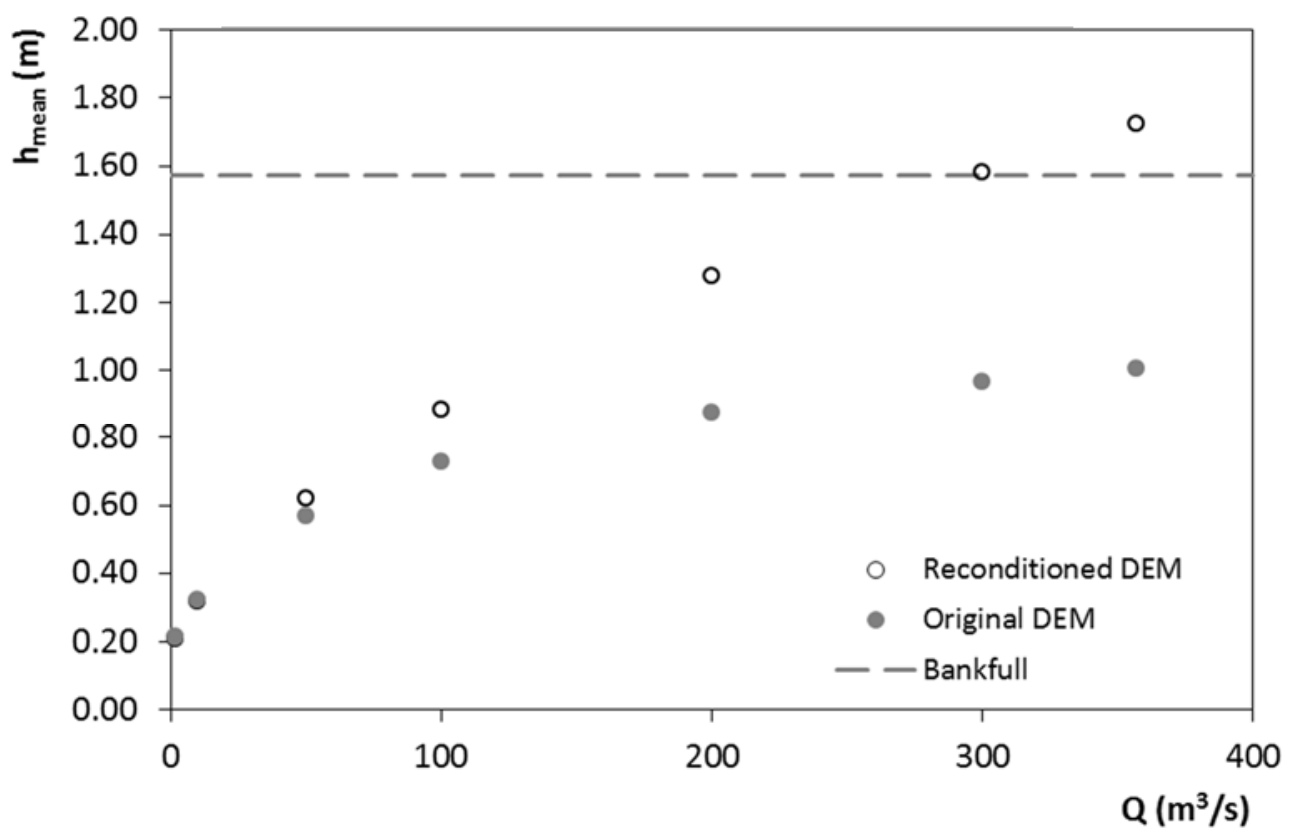

Figure 6: Average mean depth in the reach with the original DEM and the conditioned DEM for different flow discharges. The most likely estimate of bankfull depth based on empirical regressions [18] is plotted in dotted line.

Fig. 7 shows the predicted water depth field for a discharge of $300 \mathrm{~m}^{3} / \mathrm{s}$, which is close to the mean annual flow. Major flooding is predicted by the model which relies on the original DEM, whereas minor flooding is predicted with the reconditioned DEM. Very low water depths are predicted along the main channel in the first case, which results in low average depths values in the reach, as illustrated in Fig. 6. This unrealistic flow patterns seem to be due to non-physical elevations present in the DEM, which result in flow blockages and channel overflows.

\section{CONCLUSIONS}

In this study we evaluate the utility of Airbus WorldDEM topographic data for flood modelling in the data-scarce region of Cabo Delgado, Mozambique. A shallow water model of a 3.5-km reach of the Megaruma River was developed based on Airbus WorldDEM data.

The results show that the bankfull capacity of the stream is considerably underestimated when this DEM is used. This results in an overestimation of flood extents, with flooding occurring at very low flows. The application of a terrain reconditioning process that enforces realistic channel elevations into the original DEM data significantly improves model predictions. The results suggest that, in spite of the hydrological editing to which it is subject, WorldDEM dataset still presents limitations that prevent it from being directly used without further processing in local flood modelling studies. 


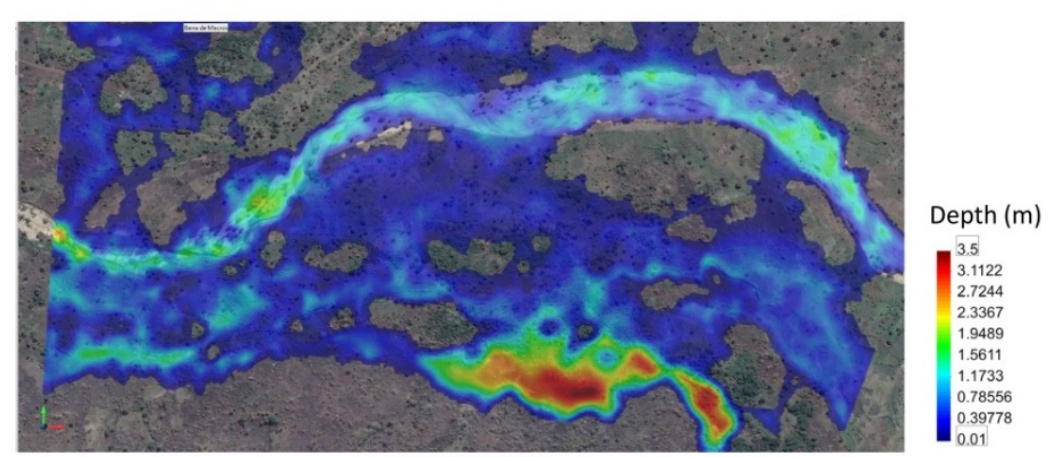

(a) Original DEM

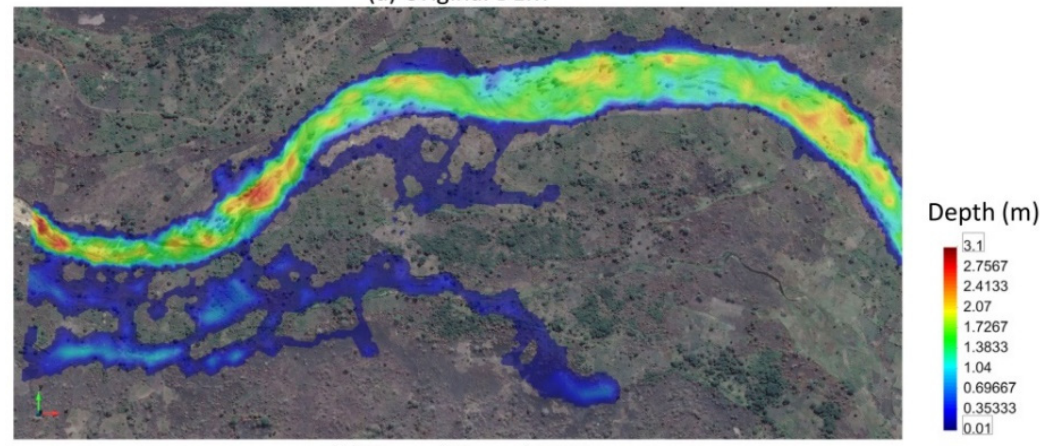

(b) Reconditioned DEM

Figure 7: Predicted water depth map in the reach with the original DEM and the conditioned DEM for a discharge of $\mathrm{Q}=300 \mathrm{~m}^{3} / \mathrm{s}$.

\section{ACKNOWLEDGEMENTS}

The authors would like to acknowledge the Spanish Regional Government of Galicia for funding the projects SIXHIARA-fase III (PR 803D 2015/54), INUNARA (PR 815 A 201411) and SECARA (PR 815A 2017/5). María Bermúdez gratefully acknowledges financial support from the Spanish Regional Government of Galicia (Postdoctoral grant reference ED481B 2014/156-0).

\section{REFERENCES}

[1] Roca, M., Martín-Vide, J.P. \& Moreta, P.J.M., Modelling a torrential event in a river confluence. Journal of Hydrology, 364(3-4), pp. 207-215, 2009.

[2] González-Sanchis, M., Murillo, J., Latorre, B., Comín, F. \& García-Navarro, P., Transient two-dimensional simulation of real flood events in a Mediterranean floodplain. Journal of Hydraulic Engineering, 138(7), pp. 629-641, 2012.

[3] Bermúdez, M. et al., Quantifying local rainfall dynamics and uncertain boundary conditions into a nested regional-local flood modelling system. Water Resources Research, 53(4), pp. 2770-2785, 2017.

[4] Bermúdez, M. \& Zischg, A.P., Sensitivity of flood loss estimates to building representation and flow depth attribution methods in micro-scale flood modelling. Natural Hazards, in press. 
[5] De Almeida, G.A.M., Bates, P. \& Ozdemir, H., Modelling urban floods at submetre resolution: Challenges or opportunities for flood risk management? Journal of Flood Risk Management, 11, pp. S855-S865, 2018.

[6] Sanders, B.F., Evaluation of on-line DEMs for flood inundation modeling. Advances in Water Resources, 30, pp. 1831-1853, 2007.

[7] Yan, K., Di Baldassarre, G., Solomatine, D.P. \& Schumann, G.J.P., A review of lowcost space-borne data for flood modelling: Topography, flood extent and water level. Hydrological Processes, 29, pp. 3368-3387, 2015.

[8] Tarekegn, T.H., Haile, A.T., Rientjes, T., Reggiani, P. \& Alkema, D., Assessment of an ASTER-generated DEM for 2D flood modelling. International Journal of Applied Earth Observation and Geoinformation, 12, pp. 457-465, 2010.

[9] Sampson, C.C., Smith, A., Bates, P.D., Neal, J.C. \& Trigg, M.A., Perspectives on open access high resolution digital elevation models to produce global flood hazard layers. Frontiers in Earth Science, 3, pp. 1-6, 2016.

[10] Álvarez, M., Puertas, J., Peña, E. \& Bermúdez, M., Two-dimensional dam-break flood analysis in data-scarce regions: the case study of Chipembe Dam, Mozambique. Water, 9(6), p. 432, 2017.

[11] Universidade da Coruña, Manual Técnico de Planificação e Gestão de Infraestructuras Hidráulicas das Bacias Internas de Cabo Delgado (Technical Manual for Planning and Management of Hydraulic Infrastructures in the Interior Catchments of Cabo Delgado). Internal Report, Universidade da Coruña: A Coruña, España, 2014.

[12] SIXHIARA III: Estudo de inundações dos trechos baixos dos rios Megaruma e Messalo. Fortalecimento das capacidades técnicas da Administração Regional de Águas do Norte "ARA-Norte" no âmbito dos Sistemas de Informação Geográfica, da hidrogeologia e hidrologia. Fase III. ARA-Norte, ICARTO e GEAMA. Cabo Delgado, Pemba, 2016

[13] SWECCO, Desenvolvimento da monografia da bacia hidrográfica do rio Rovuma e da estratégia conjunta da gestão integrada dos recursos hídricos. Relatório da monografia ANEXO 2 Recursos Hídricos. SWECCO International and Associates, 2001.

[14] Collins, J., Riegler, G., Schrader, H. \& Tinz, M., Applying terrain and hydrological editing to TanDEM-X data to create a consumer-ready WorldDEM product. The International Archives of Photogrammetry, Remote Sensing and Spatial Information Sciences, 40(7), p. 1149, 2015.

[15] Bladé, E. et al., Iber: Herramienta de simulación numérica de flujo en ríos. Revista Internacional de Métodos Numéricos para Cálculo y Diseño en Ingeniería, 30, pp. 1$10,2014$.

[16] Cea, L. et al., IberWQ: New simulation tool for 2D water quality modelling in rivers and shallow estuaries. Journal of Hydroinformatics, 18, pp. 816-830, 2016.

[17] Lindsay, J., The practice of DEM stream burning revisited. Earth Surface Processes and Landforms, 41, pp. 658-668, 2016.

[18] Moody, J. \& Troutman, B., Characterization of the spatial variability of channel morphology. Earth Surface Processes and Landforms, 27(12), pp. 1251-1266, 2002.

[19] Williams, G., Bank-full discharge of rivers. Water Resources Research, 14(6), pp. 1141-1154, 1978. 